Protestantismo em Revista é licenciada sob uma Licença Creative Commons.

http://dx.doi.org/10.22351/nepp.v43i01.2956

\title{
A moralidade bíblica
}

\author{
The Bible morality
}

Ricardo Mendes de Oliveira*

\begin{abstract}
Resumo
Esse estudo se dedicou à origem do bem e do mal na Bíblia. Com o intuito de desmistificar a moralidade bíblica, foram utilizadas fontes literárias e históricas que remontam a esse documento. As histórias nela contida foram comparadas às histórias pagãs. Utilizou-se a Bíblia e a obra Paradise Lost de John Milton, para um paralelo entre o Deus existente nessas duas obras. $\mathrm{O}$ resultado foi que Deus mente e é complacente com a mentira, então a moralidade da Bíblia é mito.
\end{abstract}

\section{Palavras-chave}

Bem. Mal. Deus. Moralidade.

\begin{abstract}
This study has been devoted to the origin of good and evil in the Bible, in order to demystify the biblical morality, literary and historical sources were used that date back some biblical stories and they were compared to pagan stories. We used the Bible and Paradise Lost by John Milton, comparing the character God of these two books. The result was that God lies or at least He favors mendacities, then the morality of the Bible is a myth.
\end{abstract}

Keywords

Good. Evil. God. Morality.

\section{Introdução}

A Bíblia ganhou, ao longo da história, um lugar de destaque nas sociedades ocidentais, a tal ponto de virar instrumento de poder do homem sobre o próprio homem. No Brasil, isso não é diferente, visto que no país tem hoje diversos programas de televisão dedicados à pregação do Evangelho segundo a Bíblia, esse é um fenômeno nunca visto. $\mathrm{O}$ conceito de moralidade cristã vem da Bíblia, mas, em meio aos fiéis, esse conceito não é debatido e menos ainda questionado, pois para crer não há necessidade de evidências. Então, surge a necessidade de uma pesquisa concernente à origem do bem e do mal, e uma análise quanto à moralidade do personagem Deus na Bíblia no intuito de desmistificá-la.

[Texto recebido em março de 2017 e aceito em junho de 2017, com base na avaliação cega por pares realizada por pareceristas ad hoc]

* Docente de Língua Inglesa no Instituto Federal de Educação, Ciência e Tecnologia do Amazonas, Campus Coari. E-mail: perusalswain@gmail.com 
Analisaremos o personagem Deus na Bíblia e na obra Paradise Lost de Milton, e veremos que esse personagem está fora dos padrões morais da sociedade atual, visto que os escritores que os criaram, viveram em sociedades antigas.

Esse trabalho apresenta pesquisas feitas sobre origem de algumas estórias bíblicas, comparando-as com estórias de origem pagã mais antigas, tais como: mitologia grega, as histórias de Zoroastro, com o desígnio de oferecer aos fiéis uma explicação de cunho científico-racional para a origem dessas narrativas, combatendo assim o fanatismo religioso e seu absolutismo, que aparenta ser o grande malefício do mundo atual.

\section{Material e métodos}

Os materiais usados foram bibliográficos e devido à escassez de materiais em Língua Portuguesa, utilizou-se livros e artigos em Língua Inglesa, foram utilizados diversos autores, como pode ser constado nas referências bibliográficas, e suas teorias e na subjetividade do assunto. Utilizou-se também a flexibilidade, por causa dos possíveis caminhos que a pesquisa poderia seguir. Deu-se ênfase no processo e no entendimento do tema e não em seu resultado, usando fortemente o contexto das obras e textos. $O$ pesquisador expressou sua opinião com base nos atores mencionados, influenciando e sendo influenciado pelos textos, devido ao impacto da pesquisa.

\section{Resultados e discussão}

As diferenças semânticas entre Luz e Trevas são vitais para se entender e analisar as personagens Deus na Bíblia e na obra o Paradise Lost de John Milton. Começamos pela luz. Historicamente, durante o dia, as pessoas trabalham e, as atividades às quais a raça humana gasta a maior parte de sua energia são durante o dia, há muito movimento durante o dia, e também é onde há teoricamente menos perigo, uma vez que se pode enxergar com nitidez, aumenta-se o escapar dos perigos, sendo assim, é fácil supor por que o Bem ou Deus ou até mesmo a segurança e o conhecimento são associados à Luz. Já as Trevas são associadas semanticamente à inatividade, pois na noite, historicamente não se trabalha, mas se descansa, essa inatividade atinge também a Morte, fazendo com que a noite (trevas) seja associada a ela. A noite também pode ser associada ao perigo, pois nossos ancestrais dormiam quando a luz do sol desaparecia, e ficavam vulneráveis aos ataques de ferozes animais.

A Noite era perigosa para nossos ancestrais e outros primatas diurnos. O medo do escuro pode ter evoluído logo após os primatas noturnos tornarem-se ativos durante o dia. Nosso sistema visual evoluiu para vermos cores durante o dia, ele não funciona eficientemente sobre pouca luz. Muitos predadores perigosos (hienas, felinos grandes, lobos, serpentes) caçam primariamente à noite. Nossos ancestrais à noite, descansavam dos longos períodos de caça e coleta de fruta do dia, e poderiam ficar sem abrigo no 
crepúsculo. O pôr do sol poderia ser um forte sinal para que eles retornassem para algum lugar seguro antes do cair da noite. ${ }^{1}$

O imperador Constantino se converteu ao cristianismo no século IX d.C, isso deu poder aos líderes cristãos da época, ${ }^{2}$ pois Roma era o grande império daquele tempo. $\mathrm{O}$ temor quanto à popularidade dos deuses pagãos fez com que os líderes cristãos atribuíssem características do deus Pã (grego) a Satanás (chifres, dentes afiados, pelo e semelhança de bode) em uma tentativa de frear a popularidade dele. ${ }^{3}$ Os líderes cristãos da época poderiam ter se aproveitado dessa memória de medo que herdamos de nossos antepassados para controlarem os cristãos através do temor de feras. Esse medo seria, séculos depois, utilizado de forma muito lucrativa por Hollywood em seus filmes de terror.

O dualismo, provocado pela rotação do planeta Terra (Luz e Trevas), foi o que mais influenciou o desenvolvimento psicológico e biológico do Homem. Dessa perspectiva biológica, "dia" é o período em que o homem executa um vital e dinâmico desenvolvimento; vendo e escutando, ele explora todas as possibilidades ao máximo. Contudo, "a noite", por causa de seu estado de trevas, facilita o descanso, um estado passivo e para um desenvolvimento vital, é inativo. As características conformariam o sentido denotativo, mas a luz e as trevas servem, sincrônica e diacronicamente, como veículo aos valores emotivos e conotativos. O sentido conotativo conforma um campo mais amplo que o sentido denotativo. O homem primitivo refletiu sua crença intrínseca de um "Ser Eterno" por causa das forças cosmo-telúricas, ou seja, o homem primitivo criou seus deuses através das luzes dos corpos celestiais, vistos do Planeta Terra.

Por essa crença, o homem criou uma cosmogonia particular, formada por personificações de matérias celestiais e fenômenos atmosféricos, a respeito do dualismo (dia e noite) antes de se inventar a mitologia, atribui-se diversas conotações significativas à luz e às trevas, como fenômenos naturais e cósmicos, os quais acontecem um após o outro em ciclos e em harmonia perfeita. Luz é associada a Deus e a escuridão a Satanás. ${ }^{4}$ Predadores grandes, que podem ameaçar um humano adulto, têm dentes e presas pontiagudas. Muitos mamíferos grandes que pastam têm chifres, cascos, e galhadas afiadas. Eles usam os chifres em disputa sexual; eles os usariam contra um ataque de caçadores humanos. Quanto às outras potencialidades perigosas, podemos ter medo ou estarmos atraídos por elas. Temos um profundo medo de dentes afiados e longos. Os

1 ORIANS, G. H. Snakes, Sunrises, and Shakespeare: How Evolution Shapes Our Loves and Fears. 2. ed. Chicago: Chicago Press, 2014.

2 BARDILL, J. Constantine Divine Emperor of Chistian Golden Age. 2. ed. NewYork: Cambridge University, 2012.

3 WADDELL, T. Cultural Expressions of Evil and Wickedness: Wrath, Sex, Crime. 2. ed. Amsterdam: Rodopi, 2003.

4 USÓN, R. M. The Semantics Field of Light and Darkness in Paradise Lost. Zaragoza, 1990. Disponível em: <http://sederi.org/docs/yearbooks/01/1_13_mairal.pdf>. Acesso em: 19 set. 2016. 
maiores de muitos primatas têm caninos proeminentes, eles os usam para ameaçar e lutar contra os inimigos. A lenda do Drácula continua a inspirar medo. ${ }^{5}$

Peter Stanford afirma, em seu livro The Devil: Biography, ${ }^{6}$ que foi o profeta Zoroastro quem literalmente rompeu com a tradição de vários deuses e demônios. Zoroastro viveu na Mesopotâmia, e inventou o primeiro personagem, que tem forças e metas parecidas com o Demônio no Cristianismo. São poucos os detalhes sobre sua vida, mas acredita-se que tenha vivido no final do século VII a.C, ele nasceu no meio do século VIII a.C em Bactria (hoje conhecido como Irã). Ele abandonou a tradição anciã da Mesopotâmia, que consistia em deuses hipócritas, algumas vezes considerados bons e, em outras, maléficos, exercendo suas forças sobre os seguidores pelas forças da natureza, e ele ensina seus discípulos que há duas forças contrárias e equivalentes, uma delas é positiva e a outra negativa, ao rebaixar os deuses existentes a papéis menores, Zoroastro eleva Ahura Mazda, deus da luz, esse estava acima dos outros deuses. Ahura Mazda procura colocar leis e ordem na natureza, contra Ele, estava o demoníaco Angro Mainysh (Ahriman), essas eram as forças na natureza. Todo Bem vinha de Ahura Mazda e todo o mal de Ahriman. Zoroastro é o primeiro registro de Dualismo, ele acreditava que o mundo poderia ser dividido entre preto e branco, sem um terceiro poder onipotente.

Alguns discípulos de Zoroastro, anos depois, falaram que o Espírito Santo (Spenta Mainyu) é um dos dois espíritos em conflito com Ahriman (o mal) nesse sistema, Ahura Mazda era o todo poderoso e criou dois espíritos gêmeos: o bem e o mal, e os deixou para lutarem pelas almas da humanidade. Ahura Mazda era um juiz de última instância, que os dá liberdade nas ações, mas não permite a vitória final ao mal. Essa noção de um deus supremo tendo a palavra final sobre o diabo está presente nos ensinamentos cristãos. É difícil não detectar a figura de Ahriman como um protótipo do demônio que os cristãos acreditam ser real. Descrito como o mal, uma força cósmica a rivalizar com o deus bom, ele é comparado por Zoroastro a uma serpente. Já que o demônio é o responsável pelos sete pecados capitais no cristianismo. Ahriman era servido por sete arque-demônios: heresia, visão deturpada, anarquia, discórdia, presunção, fome e sede. Para Ahriman (deus do mal) foi dado um lugar vazio, semelhante ao inferno. Nos ensinamentos de Zoroastro: na morte a alma passa por Cinvato Peretush que é 'uma espécie de ponte', onde aqueles que pecaram seriam puxados para baixo para serem punidos eternamente por Ahriman. Todos que são puxados para debaixo dessa ponte são os que Zoroastro descreveu como mentirosos. Tempos depois, os escritores cristãos se utilizaram muito desse fato como podemos ver no Evangelho de João (8.44). Sem dúvida alguma, toda a noção de ponte ecoou no conceito cristão de escada para o céu. No Velho Testamento, não há menção do inferno. O inferno surge no Novo Testamento com Jesus alertando para ter-se cuidado com o Gehenna, que era onde se queimavam o lixo e os corpos dos criminosos crucificados

ORIANS, 2014, p. 49.

6 STANFORD, P. The Devil Biography. 2. ed. UK: Arrow Books, 2010. 
na antiga Jerusalém. Com o tempo, esse local foi ganhando fama de ser sobrenatural, e foi dele que se criou o inferno. ${ }^{7}$ Há outros paralelos entre os ensinamentos de Zoroastro e dos cristãos. Ambos avisam que uma grande crise mundial está próxima, e antecipam o dia do julgamento final. O Zoroatrismo fala sobre um salvador, criado pela semente de Zoroastro que irá vir salvar o mundo (no cristianismo é a semente de Davi, no caso Jesus Cristo) "Este será grande, e será chamado filho do Altíssimo; e o Senhor Deus lhe dará o trono de Davi, seu pai" (Lucas 1.32). A troca entre o Zoroatrismo, o Judaísmo e o Cristianismo foi historicamente, geograficamente, e culturalmente bem estabelecida. Embora seja uma minoria que pratique culto a Zoroastro, ele teve uma influência gigantesca em diversos grupos, o mais notório deles são os gnósticos que enfraquecem os argumentos cristãos de dualismo entre o bem o mal no mundo com a história de Zoroastro. A expulsão de Satanás do Céu pode ter sido inspirada na mitologia grega na história de Tifão sendo expulso por Zeus já que essa história foi escrita cerca de 550 a.C. ${ }^{8}$

Embora fique a impressão que os escritores cristãos tenham copiado o modelo literário de Zoroastro, pois demonstradas foram as semelhanças em ambas as estórias (Deus foi inspirado no personagem Ahura Mazda, e o Diabo em Ahriman). Deus na obra o Paradise Lost e também na Bíblia (Conhecedor do Bem e do Mal) está longe de ser uma figura que representa apenas o bem. Em diversas ocasiões e passagens, ele demonstra praticar o mal, e ainda mais, ser Ele próprio o criador do mal. Como podemos verificar em Lamentações 3.38: “Não sai da boca do Altíssimo tanto o mal como o bem?" e em Isaías 45.7: "Eu formo a luz, e crio as trevas; eu faço a paz, e crio o mal; eu sou o Senhor, que faço todas estas coisas". Milton parece se colocar (na obra o Paradise Lost) como remediador entre os homens e Deus, tentando de certa forma "limpar a barra" pelos males cometidos por Deus aos homens. O escritor inglês tenta justificar as maléficas atitudes tomadas por Deus, para alcançar Sua meta que seria salvar a humanidade. O Deus descrito na Bíblia também se mostra complacente quanto à mentira, como veremos mais adiante. Há algumas diferenças entre o Deus da Bíblia e o do Paradise Lost. A grande diferença entre eles é que o da Bíblia se arrepende, isso pode ser provado nas estórias de Noé, em que Ele se arrependeu de ter criado a humanidade. No Book III da obra Paradise Lost, Deus se absolve da culpa pela queda do homem, dizendo que o criou perfeito e com o livre arbítrio, então se ele caísse, era por pura e exclusiva culpa do próprio Adão. Jesus faz o mesmo que Moises fez em Exxodo 32, ele argumenta com Deus. ${ }^{9}$ Jesus sabia que para todo pecado ou desobediência, a punição de Deus é sempre a destruição. Contanto, Jesus mostra a Deus que se a raça humana fosse destruída, viriam questionamentos tais como; por que criar o homem se Deus já sabia que ele iria cair? Só para destruí-lo? Satanás sairia vitorioso. Então Deus diz que as palavras de Jesus eram as que estavam nos pensamentos

$7 \quad$ MILLS, W. Mercer Dictionary of the Bible. 2. ed. Georgia: Mercer University Press, 1990.

8 CARUS, P. History of the Devil and the Idea of Evil From The Earliest Times to The Present Day. 2. ed. 1899.

9 BRYSON, M. "That far be from thee": Divine Evil and Justification in Paradise Lost. 2002. Disponível em: <http://onlinelibrary.wiley.com/doi/10.1111/1094-348X.00033/epdf>. Acesso em: 19 set. 2016. 
do Todo Poderoso, e decide salvar o homem, mas logo em seguida diz que o homem deve morrer a menos que um ser celeste morra em seu lugar, Jesus se oferece e isenta Deus de cometer uma maldade contra a raça humana. Se colocarmos a humanidade como filhos de Deus, e pegarmos uma visão mais moderna sobre educação de filhos tais como essa citação.

Também há uma evidência clara (que reforça o senso comum) que indica a importância do estudo sobre a conduta de pais. Por exemplo, foi descoberto que crianças com problemas de conduta tinham pais que exerciam autoridade sobre elas (os filhos), com atitudes altamente similares ao problema de conduta delas. Em suma, esses pais tendiam a exercer autoridade de forma negativa comparado ao outro grupo de pais cujos filhos não tinham problema com conduta. ${ }^{10}$

Nessa citação, podemos perceber que Deus não é inocente na queda do homem, já que os filhos refletem as atitudes dos pais, Deus é conhecedor e praticante do Bem e do Mal sendo assim é natural que seus filhos (Adão e Eva) sejam altamente curiosos concernente ao bem e mal ao ponto de praticá-los.

Pamela Meyer, uma especialista em detectar mentiras, diz: a mentira é um ato cooperativo, uma mentira não tem força ao ser meramente pronunciada, ela tem poder quando alguém concorda com ela e a aceita. Estamos sempre dispostos a fazer trocas (por coisas que desejamos ardentemente). Desejamos ser um pouco mais isso ou aquilo, ou ser melhor com isso ou naquilo, é por isso que mentimos; para preenchermos esse vazio. ${ }^{11}$ Aparentemente Deus no Paradise Lost mente, pois se ele fosse realmente conhecedor de tudo, por que esperar que Jesus $O$ lembrasse sobre os resultados de exterminar a raça humana? E por que disse que iria salvar o homem, e logo diz que o homem deveria morrer se ninguém não morresse por ele?

A única maneira de livrarmos Deus do Paradise Lost de ser um mentiroso é se nos colocarmos como advogado Dele aos homens, para tentarmos redimir Suas maldades e supostas mentiras, temos que imaginar ou supor até mesmo inventar que Deus já sabia que Jesus iria aceitar o sacrifício para salvar a raça humana (apesar do texto não dizer) já que supostamente ele seja conhecedor de tudo, para que assim a suposta misericórdia divina reinasse sobre ela, e mesmo sabendo o que Jesus iria dizer sobre a destruição da humanidade e o triunfo de Satanás, Ele decide permanecer em silêncio (por algum motivo além da compreensão humana). O texto apenas menciona que Deus diz que já sabia de tudo. Mas o Deus da Bíblia parece ser evidentemente um mentiroso, esse fato foi abordado por Bryson em seu artigo. ${ }^{12}$ No título "The Father of Lies", ele argumenta que Deus mente ou pelo menos é complacente com a mentira. Podemos comprovar isso nas seguintes

10 MILNE, D. Training Behaviour Therapists. 2. ed. New York: Routledge, 2015.

11 MEYER, P. Liespotting: Proven Techniques to Detect Deception. 2. ed. New York: St. Martin Press, 2010.

12 BRYSON, 2002. 
passagens dela: "E por isso Deus lhes enviará a operação do erro, para que creiam na mentira" (2 Tessalonicenses 2.11) "Deus não é homem, para que minta; nem filho do homem, para que se arrependa; porventura diria ele, e não o faria? Ou falaria, e não o confirmaria?"(Números 23.19) "E o Senhor disse: 'enganará Acabe para que ataque Ramote-Gileade e morra lá?'; E um sugeria uma coisa, outro sugeria outra, até que, finalmente, um espírito colocou se diante do Senhor e disse: 'Eu o enganarei'. 'De que maneira?', perguntou o Senhor. Ele respondeu: 'Irei e serei um espírito mentiroso na boca de todos os profetas do rei'. Disse o Senhor: 'Você conseguirá enganá-lo; vá e engane-o'. E o Senhor pôs um espírito mentiroso na boca destes seus profetas. O Senhor decretou a sua desgraça" (1 Reis 20.22-23).

"O ladrão não vem senão a roubar, a matar, e a destruir; eu vim para que tenham vida, e a tenham com abundância" (João 10.10). Vimos que isso é mais uma mentira de Deus, pois após O sacrifício de Jesus os homens continuam a morrer tanto no Paradise Lost quanto na Bíblia. “Todavia, Deus, que é rico em misericórdia, pelo grande amor com que nos amou" (Efésios 2.4). Mas ao mesmo tempo surgem novos questionamentos tais como; se Deus é misericordioso, por que simplesmente não mostrou misericórdia à raça humana perdoando-a sem a morte de Jesus? Como já foi mencionado acima por Meyer, uma mentira só tem força quando é aceita e permitida por alguém. Esse parece ser o caso de Deus na obra Paradise Lost tendo suas mentiras aceitas pelos anjos e por Jesus.

\section{Conclusões}

Pode ser concluído então que a moralidade que supostamente adquirimos da Bíblia não passa de mito, pois foi demonstrado acima que Deus mente e comete maldades, mas surgem novas perguntas tais como; de onde vem nossa moralidade? Por que queremos bem às pessoas que não amamos? Ou até mesmo queremos ajudá-las? Por exemplo, quando ocorrem catástrofes naturais como Tsunami, as pessoas do mundo todo (ateus ou crentes) se mobilizam para ajudar?

Essas perguntas serão respondidas com mais profundidade em outros artigos, por agora podemos tentar responder a essas perguntas, com base no Darwinismo com a Seleção Natural. As abelhas, os marimbondos, formigas, cupins, e alguns vertebrados, tais como; o rato toupeiro-nu, suricata, pica-pau-das-bolotas desenvolveram uma sociedade em que os irmãos mais velhos tomam conta dos irmãos mais novos (eles estão propensos em repassar esses genes para as próximas gerações). De modo geral os animais, segundo W. D. Hamilton, tendem a cuidar, defender, compartilhar recursos, avisar de perigo, e demonstrarem outras atitudes altruístas aos seus parentes, por causa da probabilidade estatística, de seus parentes repassarem esses genes para as próximas gerações. 
Segundo Richard Dawkins, a seleção natural programou o cérebro para sentir prazer no ato sexual, no intuito de procriação. ${ }^{13}$ Hoje, mesmo com diversos métodos que previnem gestações, os seres humanos mesmo cientes QUE ao praticarem sexo que não haverá procriação sentem prazer, a programação da seleção natural está ativa. A seleção natural parece ter feito o mesmo com as atitudes altruístas e o prazer que sentimos quando temos atitudes de Bom Samaritano, seria uma atitude inconsciente no intuito de preservar a espécie e repassar os genes, como os exemplos acima. Em nossa sociedade cristã, a Bíblia parece ter usurpado esse prazer altruísta dado pela seleção natural. Obviamente esse trabalho não é uma verdade absoluta, mas serve para oferecer uma visão diferente da visão que nos é imposta de moral bíblica, desde o dia em que nascemos combatendo assim o Absolutismo e fanatismo religioso.

\section{Referências}

BARDILL, J. Constantine Divine Emperor of Chistian Golden Age. 2. ed. NewYork: Cambridge University, 2012.

BRYSON, M. “That far be from thee": Divine Evil and Justification in Paradise Lost. 2002. Disponível em: <http:/ / onlinelibrary.wiley.com/doi/10.1111/1094-348X.00033/epdf>. Acesso em: 19 set. 2016.

CARUS, P. History of the Devil and the Idea of Evil From The Earliest Times to The Present Day. 2. ed. 1899.

DAWKINS, R. The God Delusion. 2. ed. London: Bantam, 2006.

MEYER, P. Liespotting: Proven Techniques to Detect Deception. 2. ed. New York: St. Martin Press, 2010.

MILLS, W. Mercer Dictionary of the Bible. 2. ed. Georgia: Mercer University Press, 1990.

MILNE, D. Training Behaviour Therapists. 2. ed. New York: Routledge, 2015.

ORIANS, G. H. Snakes, Sunrises, and Shakespeare: How Evolution Shapes Our Loves and Fears. 2. ed. Chicago: Chicago Press, 2014.

STANFORD, P. The Devil Biography. 2. ed. UK: Arrow Books, 2010.

USÓN, R. M. The Semantics Field of Light and Darkness in Paradise Lost. Zaragoza, 1990.

Disponível em: <http://sederi.org/docs/yearbooks/01/1_13_mairal.pdf>. Acesso em: 19 set. 2016.

WADDELL, T. Cultural Expressions of Evil and Wickedness: Wrath, Sex, Crime. 2. ed. Amsterdam: Rodopi, 2003.

13 DAWKINS, R. The God Delusion. 2. ed. London: Bantam, 2006. 